剣道の突さによる気管外傷の一症例

西平 茂樹1) $・$ 山内 博幸1) $\cdot$ 江戸 雅孝 2 (2)

田中 弘 3 . 畺崎 雅和 3$)$

\title{
Cervical Tracheal Injury Due to Tuki-Waza in Kendo Match
}

\author{
Shigeki Nishihira and Hiroyuki Yamauchi \\ (Okachi Chuo Hospital) \\ Masataka Edo \\ (Akita University School of Medicine) \\ Hiroshi Tanaka and Masakazu Masaki \\ (Akita City Hospital)
}

\begin{abstract}
A rare case of cervical tracheal injury in Kendo match is reported. A 17 year old senior high school boy had sustained a shinai thrust injury to his throat during a Kendo match.

At admission, X-ray examination revealed apparent mediastinal emphysema. In the neck, chest and axilla there was marked subcutaneous emphysema. Although the trachea did not appear to be torn, there was linear coagulation at the first to third ring and the posterior wall on the mucous membrane of the trachea under bronchoscopic examination. Transnasal intubation was performed under local anesthesia. Hypoxcemia occurred three hours after intubation. Computed tomography yielded excellent information of emphysema.
\end{abstract}

Key words: tracheal injury, subcutaneous emphysema, mediastinal emphysema, Kendo thrust injury

はじめに

胸部外傷に合併する気管・気管支損傷および 喉頭・気管外傷の発生頻度はかなり低率であり, その中でもスポーツ外傷に起因する気管外傷は さらに稀である1) 8).

今回, 剣道の試合中に受けた突きによる気管 外傷症例を経験した，気管外傷そのものは軽度 であったにもかかわらず，受傷後さらに一試合
したことで著しい頸部・縦隔気腫を招来し，呼 吸困難に陥った。症例の全経過を報告すると共 に，若干の考察を加えた。

\section{症例}

患者: —, 17歳, 男子, 剣道三段.

主訴: 疼痛による頸部運動制限, 頸部腫脹(皮 下気腫), 呼吸困難（起坐呼吸).

既往歷：4 歳時より喘息あり. 12歳時, 喘息

1）秋田県厚生連雄勝中央病院耳鼻咽唉科

2) 秋田大学医学部耳鼻咽喉科学教室

3）市立秋田総合病院耳鼻咽啹科 
発作にて一カ月間入院治療したがその後発作な く, 以後治療していない.

現病歴 : 剣道の試合中, 打突のために飛び込 んだ際, 相手が繰り出した諸手突きが防具を外 れてカウンター気味に直接頸部に入った. 一瞬 呼吸が停止し発声も不能であったが，夢中であ ったため中断する事なく試合を継続, 呼吸が出 来るよらになっても数分間発声が出来なかった. 約十分後更に一試合したところ, 除々に頸部全 体が腫脹, 同時に頸部疼痛および吸気時胸部痛 と呼吸困難が出現してきたため, 同試合終了後 直ちに当院救急来院を受診した。

現症 : 意識レベル正常, 嗄声無し, 血圧正常. 頸部皮虐には胸骨頸切痕右側関節部分に一致し たごく小範囲の円形の皮下出血を認めるのみで あったが，両側鎖骨上窩，胸鎖乳突筋隆起およ

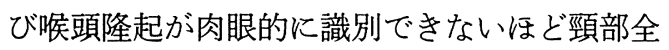
体が腫脹していた。 また, 頸胸部の疼痛と呼吸 困難が増強するため, 立位・座位以外の体位が とれない状態であった，触診により両側耳下部， オトガイ部, 頸部全体および前胸部から両腋下 部にわたる広範囲の皮下気腫が確認された. 気
管，喉頭には触診にて明らかな骨折や变位を認 めなかったが, 輪状軟骨正中部に最も強い圧痛 点が存在した. 胸部聴診で吸気呼気音に異常な く(Hamman 症候 (一)), 肺野に打ける呼吸 音の減弱等も明らかではなかった。

初診時検査所見: 受診直後の動脈血ガス分析 （13時30分，室内空気下）は, 表 1 に示したよ らに正常であったが, 単純X線写真にて頸部か ら両腋窩部に及ぶ著しい皮下気腫と上綎隔から 心外膜辺縁の透明帯と毛髮線状（矢印）陰影を 呈する明らかな縦隔気腫が認められた（図 $1 \mathrm{a}$, b, c). 心電図に特変無し. 喉頭 - 気管気管支 内視鏡検査では, 喉頭内腔の変形や粘膜の亀裂, 浮腫等は認められなかったが, 両側声帯をまた ぐように淡血性の粘液が付着していた．気管前 壁では，第 1 および第 3 気管輪に相当する部位 で気管輪に沿って少量の線状凝血が付着してい た. 気管後壁では，第 1 から第 4 気管輪に相当 する長さで膜様部に少量の凝血が縦線状に付着 していた．気管分岐部付近およびその末梢側に は明らかな異常を認めなかった。

処理 : 喉頭・気管内には線状の凝血付着部位

\begin{tabular}{|c|c|c|c|c|c|c|c|}
\hline 起座呼吸 & IIII & & & - & - & - & - \\
\hline 頭 部 痛 & + & + & + & + & - & - & - \\
\hline 胸痛 & + & + & + & - & - & - & - \\
\hline 熱 & $38^{\circ} \mathrm{C}$ & & & & & & \\
\hline 病 & 1 & 2 & 3 & 4 & 5 & 6 & 7 \\
\hline 顒曲 & $38.0 \mathrm{~cm}$ & 38.0 & 38.0 & 36.0 & 36.0 & 36.0 & 36.0 \\
\hline C $\mathrm{R} \quad \mathrm{P}$ & & 2.6 & & 5.1 & & 2. 4 & \\
\hline W B C & 12200 & & 15100 & & 10200 & & 8700 \\
\hline E $S \quad R$ & & & $18-45$ & & $60-78$ & & $65-100$ \\
\hline 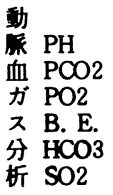 & $\begin{array}{cc}(15: 30) & (16: 14) \\
7.35 & 7.34 \\
35.5 & 37.7 \\
94.0 & 65.6 \\
-4 & -3.7 \\
20.1 & 20.8 \\
97.0 & 91.6\end{array}$ & & $\begin{array}{l}7.40 \\
36.8 \\
58.8 \\
-0.4 \\
23.3 \\
90.4\end{array}$ & & $\begin{array}{l}7.37 \\
38.8 \\
78.7 \\
-1.6 \\
22.8 \\
95.2\end{array}$ & & $\begin{array}{c}7.39 \\
39.1 \\
94.5 \\
0.1 \\
24.2 \\
97.3\end{array}$ \\
\hline
\end{tabular}

表 1 経過表 
が観察されるのみであるが，今回呼吸困難の悪 化を増長させる喉頭・気管浮腫の出現する可能 性があること，縱隔気腫の進行があれば呼吸状 態が急激に悪化する可能性があること，患者が 臥位になれず，呼吸状態の悪化の兆しがあって から気道確保を行うことは困難を要すると想像 された事，気管後壁に出血があり，あるいは食 道にも損傷が及んでいる可能性のあること，必 要が有れば後気管切開を行ら可能性のあること
の了解を本人と家族に得た上で，座位のまま局 所麻酔下に経鼻気管内挿管を行い, 経口禁, 胃 管栄養，ステロイド，抗生物質投与で経過観察 することにした．挿管チューブは，受傷部分を バイパスする事が出来れば充分と考兄，意識下 の経鼻抻管に無理の無い太さを選択し，さらに 気管損傷部をカフで軽く圧迫できればと考兄比 較的浅めに固定した.

入院後検查所見および経過：入院後の動脈血
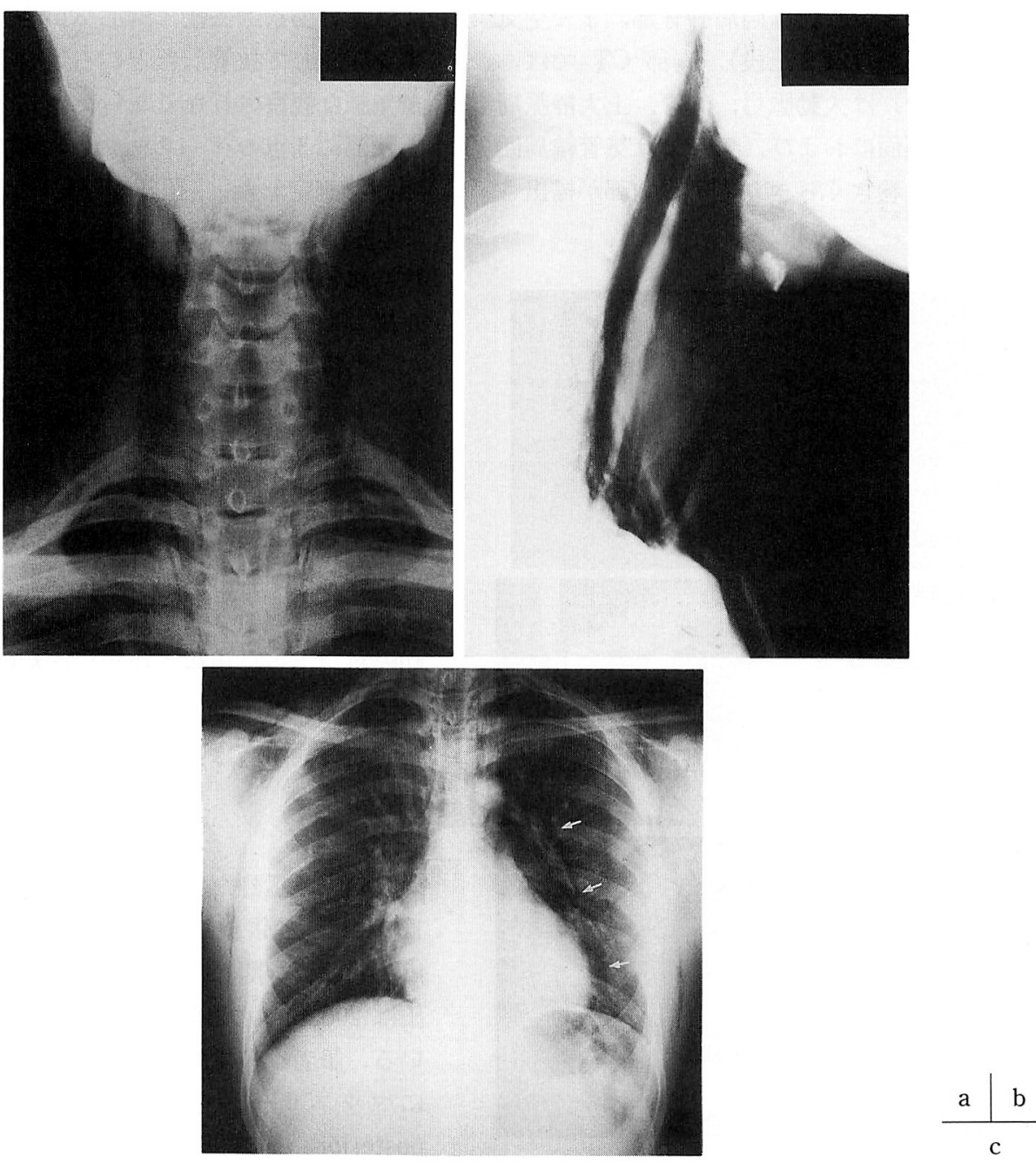

図 1 入院時の頸部正面拈よび側面像

$\mathrm{a}, \mathrm{b}:$ 胸部 X線正面像

c : 腋窩部に及ぶ皮下気腫および縱隔気腫境界毛髪線 $(\leftarrow)$ 
ガス分析（18時14分，室内空気呼吸下）で，低 酸素血症を呈した（表 1）ため，酸素（3.01 /min) 投与を開始した。

入院後の主な検査值の推移については表 1 に 示した（ガス分析は酸素投与休止後30分の時点 で施行した).

第 2 病日目に十数分の仰臥位が可能となった ため頸一胸部 CT 施行. 頸部 CT では，わかり やすいCT 解剖の図説でも見るように各器官が くっさりと空気で境界されて読影された。浅深 両筋膜を伝わって外側は両肩胛骨部，まで空気 が進入していた（図 2 上段）。胸部 CT では, 気腫（部分）は大動脈弓, 気管, 上大静脈周 囲から胸骨裏面に拈よび，気管では気管輪周囲 を空気が取り巻さくっきりとその輪郭が描出さ
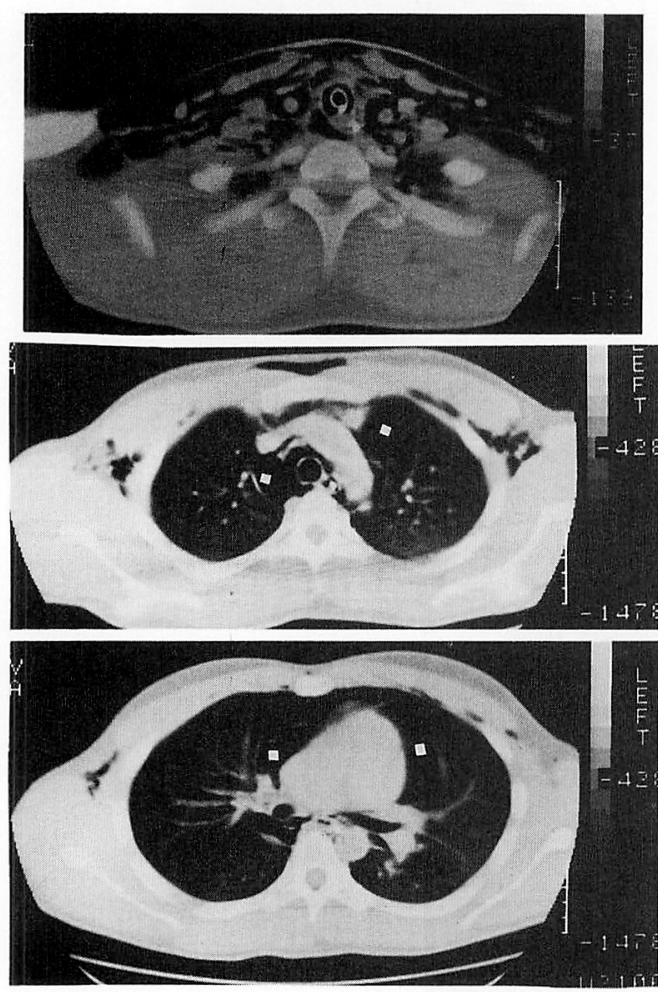

上: 頸部 CT 像

中: 胸部 CT 上縱隔大血管周囲気腫（口部分）

下：胸部 CT 心周囲気腫（口部分）
れた（図 2 中段）。心周囲では, 気腫は心臓全 体を取り囲むように存在した。一部気胸を合併 しているよらに見受けられた（図 2 下段）.

第 3 病日, 再度 CT 施行. 前日の CT で観察 された気腫は殆ど吸収されていたが，S9，10部 の無気肺が存在した. 第 $3,4,5,6$ 病日に胸 部 Xp で右下肺野の無気肺が継続して観察され たが，内視鏡下に気道分泌物を除去する事で無 気肺の改善が得られる事が確認されたため，連 日内視鏡下に分泌物を除去した。第 6 病日の朝 に気道分泌物除去後, 胸部 Xp 所見が改善した 事を確認して拔管したところ翌第 7 病日目以降, 無気肺は観察されなくなった。

頸部に 3 点のマークをつけ，常に同じ位置で 頸囲を測定した。(頸部皮下気腫が順調に吸収 された場合頸囲は小さくなるであるらし，もし 仮に気腫が進行した場合，あるいは感染が生じ た場合も一つの臨床的な指標となるものと考克 た. ) 当初 $38 \mathrm{~cm}$ であった頸囲は第 4 病日で $36 \mathrm{~cm}$ になり，その後変化しなかった．酸素投与は第 6 病日抜管後中止した.

幸いなことに深頸部・縦隔内の重篤な感染を 併発する事なく経過した。経口摂取も第 6 病日 目に抜管後，食道透視で異常を認めなかったた め開始した．第 8 病日目に患者自宅近くの耳鼻 咽喉科（市立秋田総合病院）に転院. 現在外来 にて経過観察中である.外傷後四力月が経過し た時点で，患者は剣道の稭古をしているとの事 であった。

\section{考察}

咳の際，猛烈な努力性呼吸により肺胞内圧は $100 \mathrm{~mm}$ 水銀柱以上に上昇9) し，valsalva's maneuver の際には，胸腔内圧めるいは腹腔内 圧は $200 \mathrm{~mm}$ 水銀柱にまで達する9)といわれて いる，筆者は多少剣道の経験があるため，実際 にマウスピースをロにくわ光，鼻腔通気度 posterior 法の呼吸様式で軟口蓋を安静呼吸位 に保ったまま可能な限り鼻呼吸を行いつつ素振 りをし，呼気終末にのみ軟口蓋を挙上して素振 り終了時点の口腔内圧を測定してみた（図 3 ）. 
圧変化は，マウスピースに接続した圧トランス ヂューサー (Gould Statham P-50, USA) を360 ポリグラフシステム（日本電気三栄）に組み込 んだ1273歪用へッドアンプに接続，1257血圧用 増幅ユニットで増幅して $1 \mathrm{~B} 21$ 電気眼振計で記 録した. 全システムの校正は水銀マノメータで 行った. 先ず安静呼吸時の圧を記録後, 軽い打 突を想定して 2 度素振りをし, その後最大努力 呼出時圧を記録後徐々に力をためながら強い打 突を想定して力強く素振りをしてみた. 安静呼 吸時には基線のゆれは殆ど認められないが，軽 い打突の際に約 $35 \mathrm{~mm}$ 水銀柱, 最大努力呼出 時には $115 \mathrm{~mm}$ 水銀柱, 徐々に力をためながら の強い素振りでは $105 \mathrm{~mm}$ 水銀柱に達した (図 3 ).

剣道試合時の気道内圧の著しい上昇は, 打突 の際のほんの一瞬であるが, 何回となく繰り返 される. 実験的に計測した值は，口にくわえた マウスピースを通した口腔内圧であるため, 骨 軟骨に周囲された声門部で閉鎖される事で生じ る気道内压と比較するとより低值であると考光
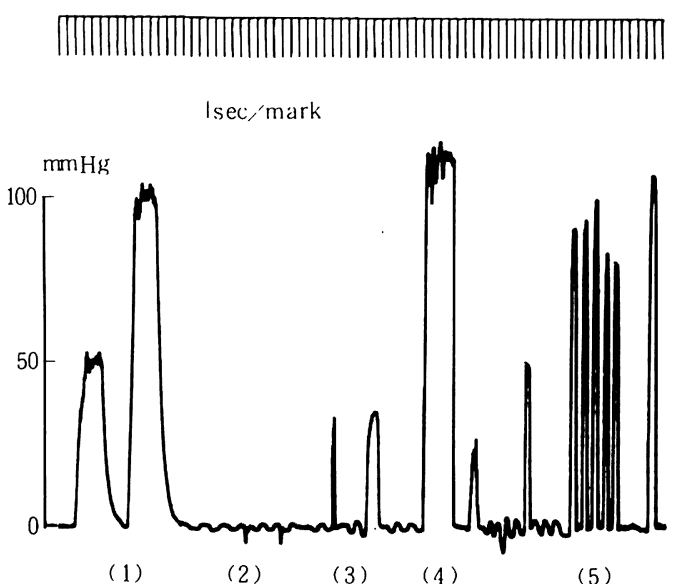

図 3 素振りの際の咽頭一口腔内圧測定記録

（1）校正（水銀血圧計による）

(2) 安静鼻呼吸時

（3）軽い打突を想定して二度素振りをした時

(4) 最大努力呼出時

（5）力を貯めながら強い打突を想定して力強 く素振りをした時
られる、また，実際の打突は呼気時に行われる ものであり, 胸部も腹壁も共にほぼマキシマム に収縮し，素振りで測定した值よりずっと高值 になる。さらに試合の間中かけている気合いで は，声門は活とんど閉じた状態であり，声門下 の気道では常にかなりの圧が負荷されていたも のと考光られる。

本症例の場合, 受傷後も試合を続行し, さら に一試合したところ, その直後から呼吸困難が 出現している，内視鏡で検索した範囲では，気 管内腔の異常所見は前後壁の線状凝血付着部分 の 3 カ所であり，仮りに同部に括いて部分的な 気管亀裂が生じていたと仮定しても受傷直後の 気腫の程度は非常に軽度であったものと予想さ れる。穞やかな呼吸の際に気道内にかかる数 $\mathrm{cm}$ 水柱の圧では, 少なくとも縦隔内への気腫 の進展は無かったであろらと考える. 気合をか けるたび，打突のたびに損傷部から空気が漏れ， 頸部一前胸部一腋窩部, あるいは縦隔内へと気 腫が進行したものと推察された。

剣道の突さといら特殊な条件下で生じた気管 外傷の発生機序に関しては想像の域を出ないが, 患者の頸部に付いた，ごく小範用の円形の皮下 出血は, 竹刀の先端が患者の前頸部を滑って着 いたものではなく, 胸骨頸切痕部で気管右側か ら左後上方に気管を的確にとらえたためのもの と考えた．気管右側部を表突きで突くと外力は 右側の胸骨頸切痕から右後上方に向い, 気管に は当たらない．以上の仮定と内視鏡所見を合わ せ考えると, 若干斜めに入った裏突きの状態で 外力が働き, 気管に亀裂が生じたものと推察さ れた。

交通災害あるいは労働災害に併発した㗋頭・ 気管外傷では甲状軟骨の骨折や気管の完全断裂 などが比較的多く報告されて拈り，また合併外 傷の程度が重大な場合が多く，そのほとんどの 症例に対し気管切開が施されている2) 4)8)。一 般に喉頭気管外傷の早期診断率は低( ${ }^{8)}$. 頸部 気管損傷では, 頸部皮下気腫が唯一の症状とし て認められる例もある10) ようであるが，鈍的 
胸部外傷に合併・起因した気管・気管支損傷で は, 呼吸困難 $72 \%$, 気胸 $67 \%$, 皮下・縦隔気腫 56 $\%$, チアノーゼ $29 \%$, 疼痛 $24 \%$, 喀血 $22 \%$, 咳 $8 \%$ であり, 受傷直後無症状のものが10\%あり, 一端症状が発現するとその進行は急速である. 受傷後の経過観察には注意を要する8). 今回の 症例の場合, 外傷の発生した状況扣よび部位が 明らかであり，食道以外の合併損傷の可能性が 殆ど考えられなかったこと，内視鏡により気管 内腔の損傷の軽微であったこと, 気腫が進行し た機序が匡湆明確であったことから, 気道確保 および血管確保が完全で有れば，急性期気管外 傷でその後起こり得る緊急の事態を回避し得る と判断し, 経鼻気管内㨉管を施した. 縦隔気腫 は高度となれば胸郭部分の圧迫感や胸内苦悶あ るいは呼吸困難等の症状が増強するばかりでな く, やがてチアノーゼ, 心・大血管の圧迫症状 として循環不全が生じる.ささらに外傷に起因す るものでは感染が加わる率が高く, 食道穿孔が 合併して执れば縦隔炎から膿瘍に進展する事が ある. 事態は急速に重篤となり緊急かつ適切な 誘導術が必要になる.

挿管の期間に関しては，気管再建の際に気管 端端吻合術後比較的短期間で抜管し得る事が報 告されている事から，5，6日6) が目安となる と考えられた.

紩隔気腫・皮下気腫の報告には, 頸胸部外傷 に併発したものと喘息発作に合併して発症した ものの報告が多(1) 3)8)11) 13)。喘息発作に合併 した縦隔・皮下気腫では, その発生機序や気腫 進展の方向が外傷の場合と異なるが，発作を押 えることで改善が見られることから，今回の症 例の場合, 外傷による気管・気管支の断裂に合 併して発症したものと比較すると, 外傷性のも のではあるものの, むしろ喘息発作に合併して 生じた縦隔・皮下気腫に類似する経過をとるで あろらと考兄られた。伊藤の報告12) では，一 回の発作後早い症例では発症後 6 日で気腫の完 全吸収がみられているが，鴨下13) は気管支喘 息に怙ける気腫軽快日数の平均は成人で 9 日と
報告している．我々の症例でも当初は一週間前 後で気腫の吸収が終了するものと考えていたが， 実際には縦隔気腫は発症後 3 日目で CT 上でも かなり吸収されていた。最も長く存在した頸部 皮下気腫も 6 日目で感知されなくなった。

CT は空気の検出に非常に鋭敏であり ${ }^{14)}$, 縦 隔, 皮下気腫の広がりや程度が正確に把握され， さらにその吸収経過から予後に大きく影響する 縱隔気腫の動態を予測する事ができ，大变有用 であった。

\section{結 語}

剣道の突きによる珍しい気管外傷の治験症例 について報告し若干の考察を加光た. 防具を外 れる突きの多さに比べ実際に外傷が発症する事 は稀であろらが，今回我々が経験したような ケースは存在する．突きにより生じ得る喉頭あ るいは気管外傷の危険性に関する認識が，選手 は勿論, 関係者や審判員並びに剣道愛好家諸兄 にも普及するように願っている.

稿を終えるにあたり，御校閲を賜りました秋田大 学医学部耳鼻咽喉科学教室戸川 清教授に深謝致し ます。また，外傷の発症機序に関して貴重な助言を 下さいました西平弘史先生（剣道教士，居合道教士） に心より拉礼申し上げます。

尚, 本論文の要旨は第60回日耳鼻秋田県地方部会 学術講演会に抌いて講演した。

\section{参考文献}

1）前中由己: 胸部外傷. 治療 $56: 559 \sim 568,1974$.

2) 栗田茂二郎：喉頭気管外傷の臨床統計的観察.

耳鼻臨床 $72: 41 \sim 49,1979$.

3）黒住静之: 喉頭気管外傷 13 症例. 耳喉 $46: 551$ $\sim 558,1974$.

4）黑住静之: 喉頭気管損傷. 耳喉 $48: 835 \sim 843$, 1976.

5）北村 武：喉頭気管外傷例. 日気食会報 15: 206, 1964.

6）米本英明：外因性喉頭外傷の 5 例. 日気食会報 $15: 206,1964$.

7）沖田和已：喉頭部外傷の一例. 日耳鼻 $10: 177$, 1959.

8) Hood RM Texas A, Sloan HE, et al : Injuries 
of the trachea and major bronchi. J Thorac Surg $38: 458 \sim 480,1959$.

9）原澤道美, 小池繁夫 (監訳)：臨床に役立つ呼吸 の生理. 264 265頁, 廣川書店, 東京, 1979.

10) Beskin CA and Ruge B : Rupture-separation of the cervical trachea following a closed chest injury. J Thorac Surg 34 : 392 394, 1957.

11）佐藤良智 : 鈍的外傷による頸部気管離断の 3 治 験例. 日胸外会誌 $27: 927 \sim 935,1979$.

12）伊藤 仁: 縦隔, 皮下気腫の 4 例. 日胸 59 :
$341 \sim 347,1984$.

13）鴨下一郎 : 発作時の合併症, 特集気管支喘息合 併症とその治療.アレルギーの臨床 $5: 205$ 208, 1985.

14）大澤忠編 : 初心者のための胸部 CT の読み方. 42 43頁, 新興医学出版社, 東京, 1987.

$$
\left(\begin{array}{l}
\text { 別刷請求先 : 西平茂樹 } \\
\text { † } 012 \text { 湯沢市表町3-3-15 } \\
\text { 秋田県厚生連雄勝中央病院耳鼻咽喉科 }
\end{array}\right)
$$

